\title{
A review of the effect of previous operations on the results of open-heart surgery
}

\author{
J. D. W ISHEAR T ${ }^{1}, D \cdot N \cdot R O S S$, and J.K. R OS S \\ National Heart Hospital, London
}

The results of open-heart surgery in a group of 50 patients who had had previous cardiac operations were analysed and compared with the results in a group of 50 patients having their first operation. The hospital mortality in the re-operated group was $22 \%$ and that in the control group was $8 \%$. Postoperative morbidity was also increased in the re-operated group. Technical hazards related to the previous operation did not contribute to the increased operative mortality, which was considered to be due to the more advanced disease present in these patients.

A number of factors may be identified in individual cases which predispose to operative death following cardiac valve replacement. Litwak et al. (1969) identified previous cardiac surgery as one important determinant of operative mortality in their series of 114 cases of mitral valve replacement: the mortality in the group of 22 patients who had had previous closed mitral valvotomy was $27 \%$ as against $9 \%$ in the remainder.

This study was designed to evaluate further the effect of previous cardiac surgery on the results of subsequent open-heart procedures, mainly valve replacements.

\section{METHODS}

For the purpose of this study a re-operation is defined as an open-heart procedure in a patient who had had a previous intrapericardial cardiac operation, thus excluding, among others, patients who had had palliation of a congenital defect by a systemic-pulmonary shunt. Between 1 January 1968 and 31 October 1969, 632 open-heart operations were carried out at the National Heart Hospital, and the 50 consecutive cases of re-operation performed during this period form the group of patients to be considered. A control group was selected by matching each re-operated case with a patient having a first operation. The criteria for selection of the control cases were that the patient (1) had the same operation, (2) was of the same sex, (3) was of a similar age, and (4) had his operation as close in time as possible to that of the re-operated case. The 50 cases and their controls are compared with regard to mortality and morbidity occurring during their stay in hospital, thus

1Present address: Department of Surgery, University of Alabama in Birmingham, 1919 Seventh Avenue South, Birmingham, Alabama 35233, U.S.A. including the periods of the operation, recovery, and convalescence. The importance of technical problems during surgery on the re-operation cases will be considered.

\section{MATERIAL}

The re-operation cases will be described in subgroups according to operation (Fig. 1).

AORTIC VALVE REPLACEMENT Re-operation with aortic valve replacement was carried out in 12 cases, using the different techniques indicated in Figure 2a. The time of the first operation and the procedure carried out on that occasion for each patient are described in Figure 2b. The preoperative functional grading (New York Heart Association) showed that the re-

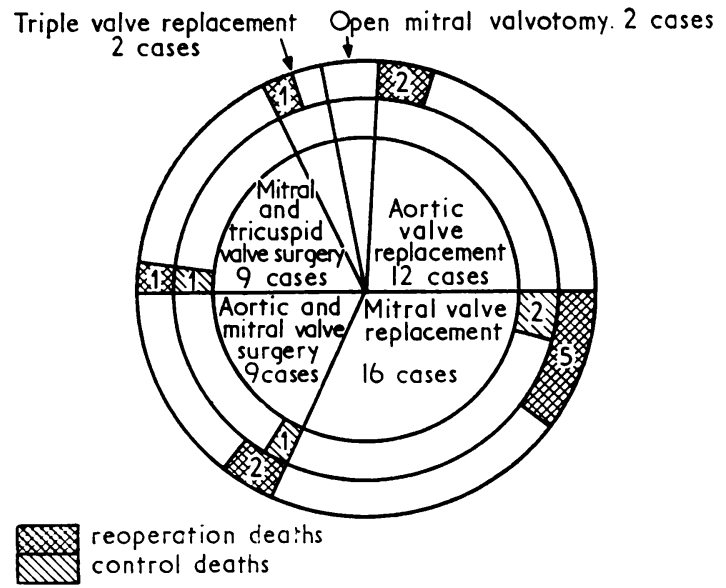

FIG. 1. Mortality in reoperated and control groups. 

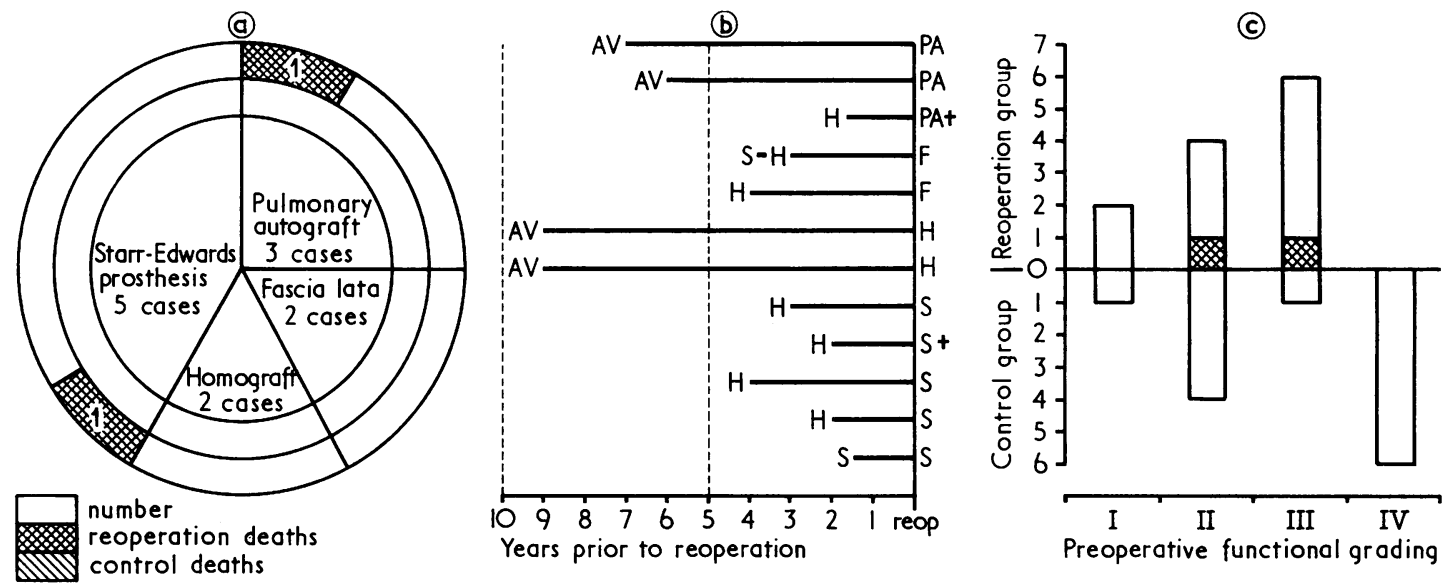

FIG. 2. Aortic valve replacement: (a) type of operation and mortality; (b) previous operations (AV=aortic valvotomy, $H=$ homograft, $S=$ Starr-Edwards prosthesis, $F=$ fascia lata valve, $P A=$ pulmonary autograft, $+=o p e r a t i v e ~ d e a t h) ;$ (c) preoperative functional grading.
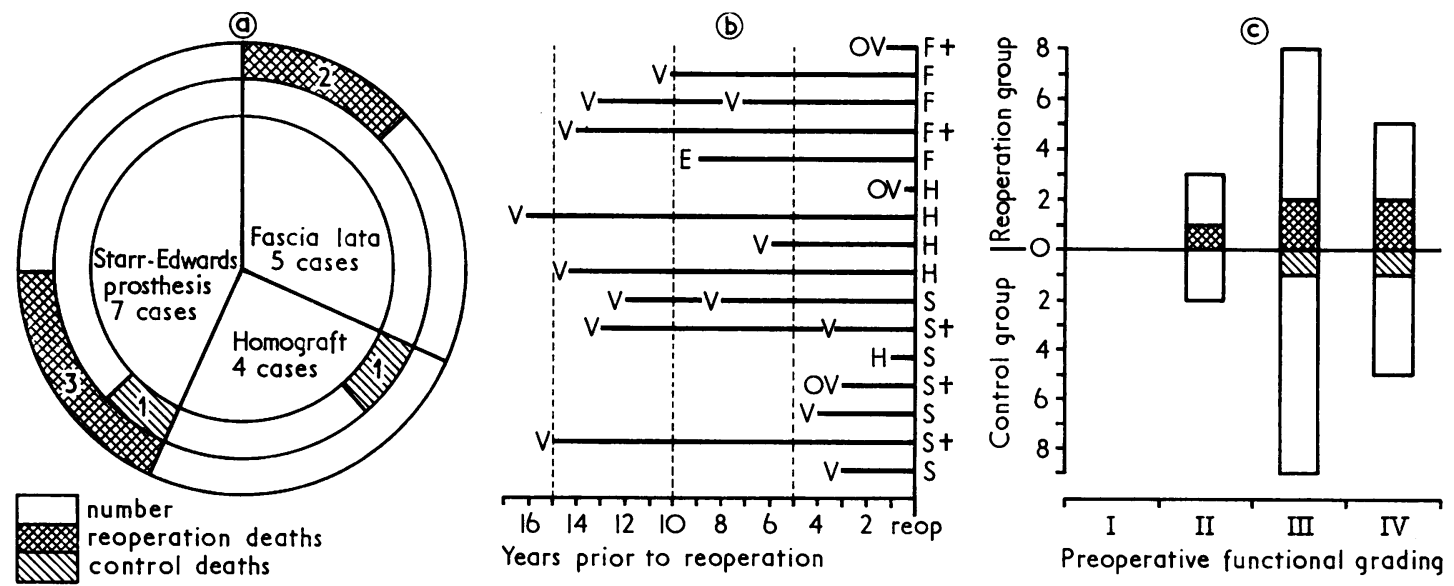

FIG. 3. Mitral valve replacement: (a) type of operation and mortality; $(b)$ previous operations ( $V=$ closed mitral $ᄋ$ valvotomy, $O V=$ open mitral valvotomy, $E=$ exploration of left atrium, $F=$ fascia lata, $H=$ homograft,$S=S t a r r-E d w a r d s ~ D$ prosthesis, $+=$ operative death); (c) preoperative functional grading.

operation group had an excess in grade III, balanced by an excess in grade IV in the control group due entirely to a high incidence of anginal symptoms (Fig. 2c).

The re-operated group included eight patients with dominant aortic regurgitation, two with dominant aortic stenosis, and two with mixed valve disease. Included among those with aortic regurgitation were five patients who had developed subacute bacterial endocarditis after the original valve replacement.

MITRAL VALVE REPLACEMENT Re-operation with mitral valve replacement was carried out in 16 cases, using the different techniques indicated in Figure 3a. The time of the previous operation and the procedure carried out on that occasion for each patient are described in Figure 3b. The preoperative functional grading was similar in the two groups (Fig. 3c).

There was dominant mitral stenosis in seven cases $\theta$ and dominant mitral incompetence in nine cases. The mean of the resting systolic pulmonary artery (PA) pressures was $73 \mathrm{mmHg}$ in the re-operation cases and 7 $57 \mathrm{mmHg}$ in the control cases (Fig. 4).

DOUBLE VALVE SURGERY: AORTIC AND MITRAL Re-

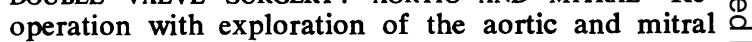
valves was carried out in nine cases using the different $\underset{\gamma}{ }$ techniques indicated in Figure $5 \mathrm{a}$. The time of the 


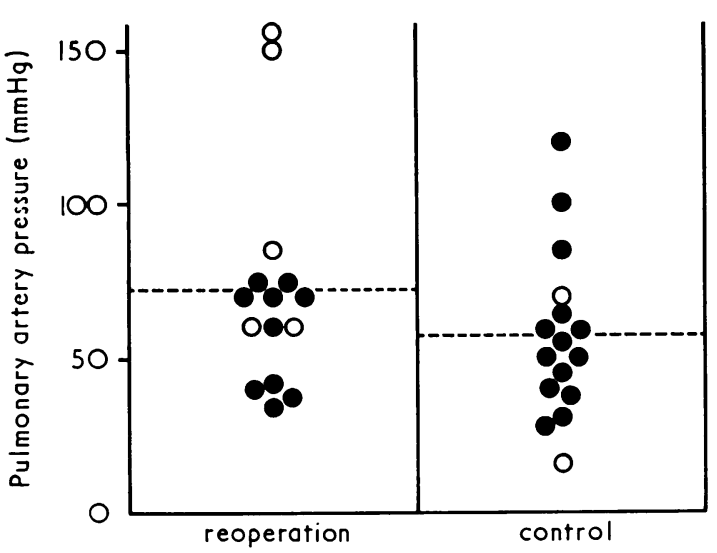

FIG. 4. Pulmonary artery pressure after mitral valve replacement: pulmonary artery pressure at rest; patient died.

previous operation and the procedure carried out on that occasion for each patient are described in Figure 5 b. The preoperative functional grading was similar in the two groups (Fig. 5c).

In the re-operated series both valves were regurgitant in five cases, with additional aortic stenosis in the remaining four cases. The mean resting systolic pressure in the two groups was $50 \mathrm{mmHg}$ and 46 $\mathrm{mmHg}$ respectively.

DOUBLE VALVE SURGERY: MITRAL AND TRICUSPID There were nine cases of mitral and tricuspid valve surgery using the techniques indicated in Figure 6a. The time of the previous operation and the procedure carried out on that occasion for each patient are de- scribed in Figure $6 \mathrm{~b}$. The functional status of the two groups was similar (Fig. 6c).

In the re-operated series there was disorganization of the mitral valve in all patients with calcification in five. There was organic tricuspid valve disease in four cases and dilatation of the annulus only in five. The mean resting systolic PA pressure was $77 \mathrm{mmHg}$, all cases having a PA pressure over $50 \mathrm{mmHg}$. In the control series the mitral valve disease was slightly less severe with mitral stenosis only in four cases and a mean PA pressure of $61 \mathrm{mmHg}$, seven cases having a PA pressure greater than $50 \mathrm{mmHg}$. The tricuspid valve disease was of similar severity with organic involvement in four patients.

OPEN MITRAL VALVOTOMY There were two patients in each group without death or serious complication.

TRIPLE VALVE REPLACEMENT Re-operation with triple valve replacement was carried out twice, using homograft and fascia lata valves in one case each. Closed mitral valvotomy had been carried out in one patient 14 years previously, while aortic valve replacement with a homograft, together with mitral and tricuspid valvotomy, had been carried out two years previously in the other. In the control series triple valve replacement was carried out using homografts and StarrEdwards prostheses in one case each. The preoperative functional grading was similar in the two groups.

\section{RESULTS}

The comparability of the re-operated and control groups may be seen in Table I. The first criterion, that of both having had the same operation, was satisfied except that details of the procedures
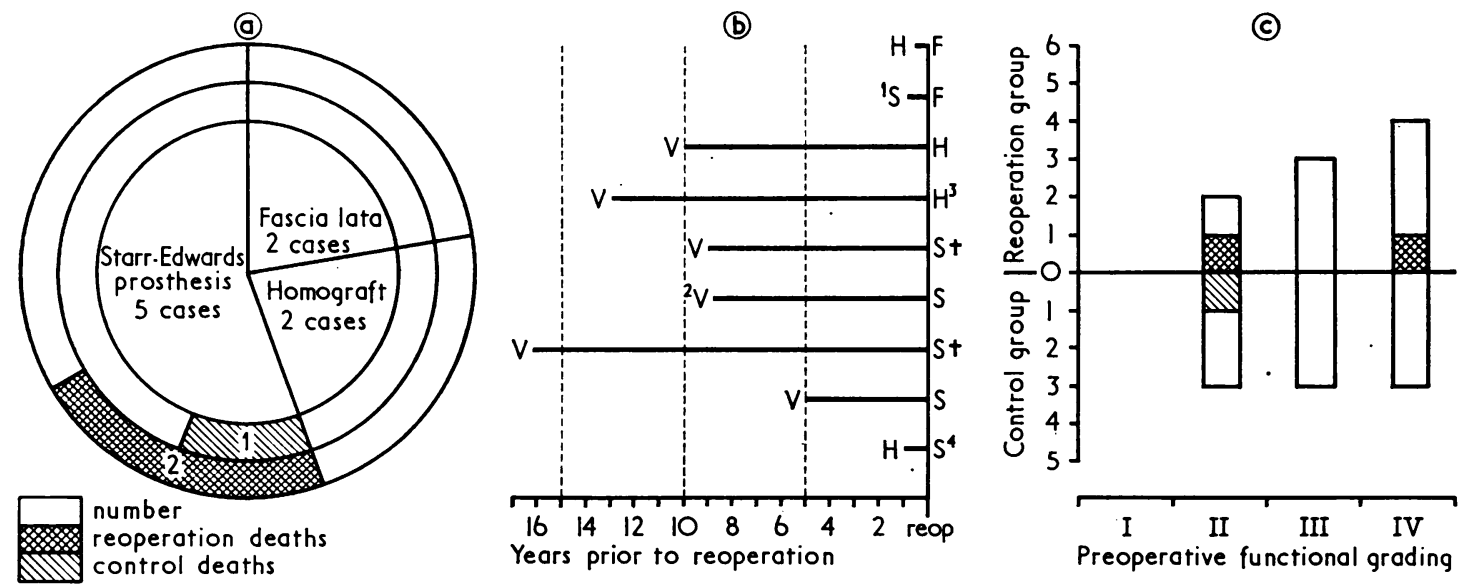

FIG. 5. Aortic and mitral double valve surgery: (a) type of operation and mortality; (b) previous operations ( $F=$ fascia lata, $H=$ homograft (double valve), $S=S$ tarr-Edwards prosthesis (double valve), $V=$ closed mitral valvotomy, $1=$ aortic Starr valve, $2=$ closed aortic and mitral valvotomy, $3=A V R$ with homograft: with mitral valvotomy and tricuspid annuloplasty, $4=A V R$ with Starr valve and mitral annuloplasty); (c) preoperative functional grading. 

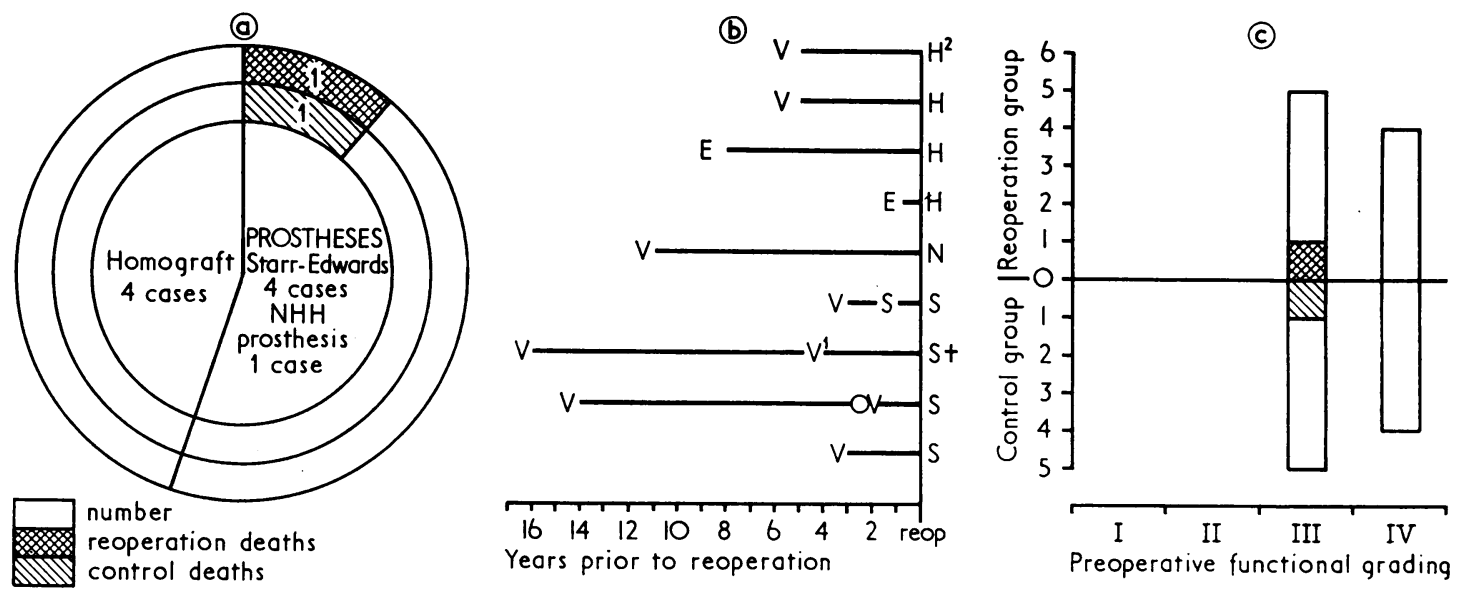

FIG. 6. Mitral and tricuspid double valve surgery: (a) type of operation and mortality; (b) previous operations ( $H=$ homograft, $S=$ Starr-Edwards prosthesis, $N=N H H$ prosthesis, $V=$ closed mitral valvotomy, $O V=$ open mitral valvotomy, $E=$ exploration mitral valve, $1=$ mitral and aortic valvotomy, $2=$ double valve replacement: all other cases had $M V R$ and tricuspid annuloplasty); (c) preoperative functional grading.

T A B LE I

\begin{tabular}{|c|c|c|c|c|c|c|}
\hline \multirow{3}{*}{ Operation } & \multirow{3}{*}{$\begin{array}{c}\text { No. } \\
\text { Patients }\end{array}$} & \multicolumn{2}{|c|}{ Sex } & \multirow{3}{*}{$\begin{array}{c}\text { Mean } \\
\text { Age } \\
(\mathrm{yr})\end{array}$} & \multirow{2}{*}{\multicolumn{2}{|c|}{$\begin{array}{c}\text { Time Elapsed } \\
\text { Between } \\
\text { Re-operation } \\
\text { and Control } \\
\text { (mth) }\end{array}$}} \\
\hline & & \multirow[t]{2}{*}{$\mathbf{M}$} & \multirow[t]{2}{*}{$F$} & & & \\
\hline & & & & & Mean & Range \\
\hline $\begin{array}{l}\text { Aortic valve replacement } \\
\text { Re-operation } \\
\text { Control }\end{array}$ & $\begin{array}{l}12 \\
12\end{array}$ & $\begin{array}{l}9 \\
8\end{array}$ & $\begin{array}{l}3 \\
4\end{array}$ & $\begin{array}{l}33 \\
39\end{array}$ & $2 \cdot 75$ & $0-11$ \\
\hline $\begin{array}{l}\text { Mitral valve replacement } \\
\text { Re-operation } \\
\text { Control } \\
\end{array}$ & $\begin{array}{l}16 \\
16 \\
\end{array}$ & $\begin{array}{l}7 \\
7 \\
\end{array}$ & $\begin{array}{l}9 \\
9 \\
\end{array}$ & $\begin{array}{l}45 \\
46 \\
\end{array}$ & 3.00 & $0-7$ \\
\hline $\begin{array}{l}\text { Aortic and mitral valve } \\
\text { surgery } \\
\text { Re-operation } \\
\text { Control }\end{array}$ & $\begin{array}{l}9 \\
9\end{array}$ & $\begin{array}{l}4 \\
3\end{array}$ & $\begin{array}{l}5 \\
6\end{array}$ & $\begin{array}{l}41 \\
47\end{array}$ & 4.44 & $1-15$ \\
\hline $\begin{array}{l}\text { Mitral and tricuspid valve } \\
\text { surgery } \\
\text { Re-operation } \\
\text { Control }\end{array}$ & $\begin{array}{l}9 \\
9\end{array}$ & $\begin{array}{l}3 \\
2\end{array}$ & $\begin{array}{l}6 \\
7\end{array}$ & $\begin{array}{l}41 \\
45\end{array}$ & $4 \cdot 89$ & $0-16$ \\
\hline $\begin{array}{l}\text { Triple valve replacement } \\
\text { Re-operation } \\
\text { Control }\end{array}$ & $\begin{array}{l}2 \\
2\end{array}$ & $\begin{array}{l}\mathbf{0} \\
\mathbf{0}\end{array}$ & $\begin{array}{l}2 \\
2\end{array}$ & $\begin{array}{l}45 \\
39\end{array}$ & $7 \cdot 5$ & $1-14$ \\
\hline $\begin{array}{l}\text { Open mitral valvotomy } \\
\text { Re-operation } \\
\text { Control }\end{array}$ & $\begin{array}{l}2 \\
2\end{array}$ & $\begin{array}{l}2 \\
1\end{array}$ & $\begin{array}{l}0 \\
1\end{array}$ & $\begin{array}{l}61 \\
51 \\
\end{array}$ & $11 \cdot 5$ & $10-13$ \\
\hline $\begin{array}{l}\text { Total } \\
\text { Re-operation } \\
\text { Control }\end{array}$ & $\begin{array}{l}50 \\
50\end{array}$ & $\begin{array}{l}25 \\
21\end{array}$ & $\begin{array}{l}25 \\
29\end{array}$ & $\begin{array}{l}41 \\
43\end{array}$ & $4 \cdot 1$ & $0-16$ \\
\hline
\end{tabular}

varied in some cases in the two subgroups of double valve surgery. The match according to sex, the second criterion, was achieved in all but four patients so that there is an excess of four females in the control group. The third criterion was age, and the mean age of the two groups as a whole differed by two years. Finally, the mean proximity in time between each pair of matched operations (re-operated and control) was four months with a range of 0 to 16 months. The reason for this rather long elapsed period between matched pairs was that during this time prosthetic valves were sometimes used in re-operated cases but only rarely in the first operations.

T A B LE II

OPERATIVE MORTALITY

\begin{tabular}{|c|c|c|c|}
\hline \multirow{2}{*}{ Operation } & \multirow{2}{*}{$\begin{array}{l}\text { No. of } \\
\text { Patients }\end{array}$} & \multicolumn{2}{|c|}{ No. of Deaths } \\
\hline & & Re-operatio & Control \\
\hline $\begin{array}{l}\text { Aortic valve replacement } \\
\text { Mitral valve replacement } \\
\text { Aortic and mitral valve surgery } \\
\text { Mitral and tricuspid valve surgery } \\
\text { Triple valve replacement } \\
\text { Open mitral valvotomy }\end{array}$ & $\begin{array}{r}12 \\
16 \\
9 \\
9 \\
2 \\
2\end{array}$ & $\begin{array}{l}2 \\
5 \\
2 \\
1 \\
1 \\
0\end{array}$ & $\begin{array}{l}0 \\
2 \\
1 \\
1 \\
0 \\
0\end{array}$ \\
\hline Total & 50 & $11(22 \%)$ & $4(8 \%)$ \\
\hline
\end{tabular}

T A B L E I I I

CAUSES OF DEATH

\begin{tabular}{l|c|c}
\hline \multicolumn{1}{c|}{ Cause } & Re-operation & Control \\
\hline $\begin{array}{l}\text { Myocardial failure } \\
\text { (a) not off bypass }\end{array}$ & 3 & 1 \\
(b) postoperative low cardiac output & 2 & 0 \\
Tamponade & 1 & 0 \\
Subacute bacterial endocarditis & 1 & 1 \\
Respiratory failure & 1 & 1 \\
Pulmonary emboli & 1 & 0 \\
Intestinal infarction \\
Respiratory failure and myocardial \\
irritability
\end{tabular}


T A B LE IV

COMPLICATIONS

\begin{tabular}{|c|c|c|}
\hline Complication & Re-operation & Control \\
\hline $\begin{array}{l}\text { No. of patients } \\
\text { No. survived operation }\end{array}$ & $\begin{array}{l}50 \\
39\end{array}$ & $\begin{array}{l}50 \\
46\end{array}$ \\
\hline $\begin{array}{l}\text { Postoperative low cardiac output } \\
\text { Early re-operation for (1) bleeding } \\
\\
\text { Complete heart block } \\
\text { (2) tamponade } \\
\text { Dysrhythmia } \\
\text { Ventilation for more than } 48 \mathrm{hr} \\
\text { Pulmonary atelectasis } \\
\text { Pulmonary embolism } \\
\text { Subacute bacterial endocarditis } \\
\text { Haemolysis } \\
\text { Post-pericardiotomy syndrome } \\
\text { Neurological } \\
\text { Psychiatric } \\
\text { Valve malfunction }\end{array}$ & $\begin{array}{l}1 \\
1 \\
1 \\
1 \\
0 \\
1 \\
8 \\
1 \\
2 \\
2 \\
1 \\
1 \\
1 \\
5\end{array}$ & $\begin{array}{l}0 \\
2 \\
0 \\
1 \\
2 \\
1 \\
8 \\
1 \\
1 \\
0 \\
0 \\
1 \\
1 \\
1\end{array}$ \\
\hline $\begin{array}{l}\text { Survivors with complications } \\
\% \text { patients with complications } \\
\text { (of survivors) }\end{array}$ & $\begin{array}{l}26 \\
19 \\
49 \%\end{array}$ & $\begin{array}{l}19 \\
17 \\
37 \%\end{array}$ \\
\hline
\end{tabular}

MORTALITY The deaths for each operation, occurring between the time of operation and the time of discharge from hospital, are represented in Fig. 1 and Table II for the re-operated and control series. In the groups as a whole the mortality was $22 \%$ in the re-operated patients and $8 \%$ in the controls (Table II). It may be seen that this difference is consistently reflected in each operation subgroup.

Three re-operation deaths occurred in the operating theatre, two in the first 48 hours after surgery and the remainder between 11 and 40 days after operation. Nine causes of death are listed in Table III, each one occurring not more than once in each group, except myocardial failure which accounted for 5 of the 11 re-operation deaths. Of these five, three could not sustain a circulation without bypass support and died in theatre; two others died following a postoperative course chiefly characterized by a low cardiac output.

COMPLICATIONS Thirty-nine patients survived re-operation and 46 survived their first operation: 26 complications occurred in $19(49 \%)$ of the 39 survivors of re-operation: 19 complications occurred in $17(37 \%)$ of the 46 patients surviving a first operation. In general, the complications were successfully managed but in a small number there were serious sequelae. The complications themselves are listed in Table IV, where it may be seen that pulmonary atelectasis occurred most commonly in each group.

Malfunction of the new valve occurred in five cases in the re-operated group and once in the control group. The fact that the patient had had a previous operation could be held responsible for valve malfunction in the one case of a peripheral leak and possibly in one more where subacute bacterial endocarditis has caused mild regurgitation. The three remaining instances were due to technical factors unrelated to previous surgery.

\section{TECHNICAL HAZARDS ARISING AT RE-OPERATION}

Among these 50 patients no technical accident occurred attributable to obliteration of the perisardium which resulted in death or serious complication. Prolongation of the duration of surgery before bypass was minimal, averaging 15 minutes for each re-operation patient when compared with control groups. The average blood requirement for each re-operation patient was 7.0 pints, compared with 6.6 pints for the controls. The intracardiac pathology found at operation was clearly more advanced in the re-operation cases, but this is difficult to measure directly. Bypass time and the duration of ischaemic arrest are indirect indices of the difficulties presented by these findings. The bypass time was longer by only 12 minutes for each re-operated patient (mean bypass time in controls: 1 hour 30 minutes) and the period of ischaemic arrest was longer by less than 3 minutes (mean period of ischaemic arrest in controls: 49 minutes).

Failure of incorporation of a new valve by tissues damaged by disease and scarred by previous surgery might be expected to lead to dehiscence of suture lines. Although there was malfunction of five valves following re-operation, it has already been pointed out that only one was due to dehiscence. Finally, a greater incidence of infection might be expected as the duration of each re-operation was altogether 51 minutes longer than for the controls (mean operation time in controls: 5 hours 48 minutes). There were three cases of subacute bacterial endocarditis in the re-operation group and two in the control group.

\section{DISCUSSION}

Any cardiac operation carries a significant risk: when a patient presents for a second operation this risk may be increased for two main reasons. First, there are the well-known technical difficulties arising from obliteration of the pericardium: bleeding from adhesions, accidental damage to a coronary artery or breach of the cardiac wall by saw or scissors. These may lead to prolongation of the operating time due to the 
difficult dissection, dysrhythmias and reduced cardiac output due to excessive handling of the heart, and finally the increased postoperative incidence of infection. Secondly, this group of patients has already had one operation, many have had a significant complication of that procedure, such as subacute bacterial endocarditis, and all are now presenting at a more advanced stage of the natural history of their disease. Thus the intracardiac pathology is likely to be more advanced and may have been made still more complex by the previous surgical manipulation. Litwak and his colleagues (1969) demonstrated a threefold increase in operative mortality among those who had had previous cardiac surgery, and this finding is confirmed here among a more comprehensive series of 50 patients. Of the six deaths in his series, two were due to technical causes and four were attributable to myocardial failure, which was the cause of 5 of the 11 deaths in the present series. Three of these hearts could not sustain the circulation without bypass support, and the other two patients died after a postoperative course characterized by low cardiac output. There were no deaths due to technical factors resulting from the previous surgery. The modest increase in operating time and blood requirements shows that the technical dangers outlined above may be avoided or minimized and need not constitute a source of hazard for the patient. The high incidence of myocardial failure in these patients must therefore be attributed mainly to the more advanced state of the cardiac disease-and in particular to its effect on the myocardium and the pulmonary vasculature. In the subgroups with mitral valve disease the pulmonary artery pressure was higher in the re-operated than in the control group. This more advanced pathology probably represents a hazard which will be reduced only by improved surgical capabilities in terms of both technique and management.

In a small number of individual patients other factors leading to death may be identified. All three patients who died in the operating theatre, unable to maintain their circulation, had had periods of elective ischaemic arrest in excess of one hour. One of these patients, and another who died following operation, had extreme pulmonary hypertension, which also emerges as an indicator of increased operative hazard. Whether or not the pulmonary vascular disease itself constitutes an increased operative risk is not certain, but it is associated with more advanced disease which has already been identified as the chief determinant of increased operative mortality in this series of patients. These findings suggest that prolonged periods of ischaemic arrest should be avoided at re-operation.

There was no difference in operation risk between those who had had previous valve replacement and those who had conservative procedures only.

Re-operation on the aortic valve was most commonly indicated for aortic regurgitation due to subacute bacterial endocarditis following previous valve replacement. In no instance did the endocarditis recur after the second operation, and the new valve remained clinically competent in the early postoperative period.

\section{CONCLUSION}

In a group of 50 consecutive re-operations, the hospital mortality was $22 \%$ compared with $8 \%$ in 50 controls. The principal mode of death was myocardial failure, which was attributed to the more advanced stage of the disease found in these patients. The technical difficulties of re-operation did not contribute to the operative mortality and morbidity. It has been shown that the increased risk was independent of whether the previous operation was conservative or a valve replacement.

We should like to thank Dr. M. Geens who first suggested this review, and Mr. J. E. C. Wright and Dr. L. Gonzalez-Lavin who read the manuscript. Mrs. R. Pritchard drew the figures and Mrs. B. Westbrook typed the manuscript.

\section{REFERENCE}

Litwak, R. S., Silvay, J., Gadboys, H. L., Lukban, S. B., Sakurai, H., and Castro-Blanco, J. (1969). Factors associated with operative risk in mitral valve replacement. Amer. J. Cardiol., 23, 335. 